\title{
Three superovulation protocols for in vivo embryo production in Santa Inês sheep
}

\author{
Eduardo Kenji Nunes Arashiro ${ }^{1}$ (i) Pedro Henrique Nicolau Pinto1(i) Julia Timponi Moura Lima ${ }^{1}$ (D) \\ Marc Henry ${ }^{2}$ (i) Fábio Otero Ascoli ${ }^{1}$ (i) Joanna Maria Gonçalves Souza-Fabjan ${ }^{1}$ (D)

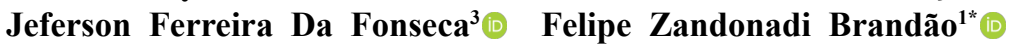

${ }^{1}$ Faculdade de Veterinária, Universidade Federal Fluminense (UFF), 24230-340, Niterói, RJ, Brasil. E-mail: fzbrandao@id.uff.br. ${ }^{*}$ Corresponding author.

${ }^{2}$ Escola de Veterinária, Universidade Federal de Minas Gerais (UFMG), Belo Horizonte, MG, Brasil.

${ }^{3}$ Embrapa Caprinos e Ovinos, Sobral, CE, Brasil.

ABSTRACT: There is still no consensus regarding the best protocol for in vivo embryo production in sheep despite increasing studies in this area. Moreover, there is variability in the response of ewes to superovulation (SOV). An approach to mitigate this inconsistency is to initiate gonadotropin administration under favorable ovarian conditions. The present study compared three treatments in a crossover design: a traditional SOV protocol (TRAD) and "Day 0" DO SOV protocol with (D0+GnRH), or without Lecilerin (D0-GnRH). Fifteen Santa Inês ewes received $200 \mathrm{mg}$ of FSH at six decreasing doses and PGF2 $\alpha$ with the fifth dose of FSH. They were naturally mated with fertile rams and subjected to surgical embryo collection. The number of viable embryos was similar among the different treatments (TRAD = 6.0 $\pm 4.7 ;$ D0$G n R H=3.8 \pm 6.4 ; D 0+G n R H=7.5 \pm 6.5)$. Regardless of the treatment method, ewes with follicles $\leq 4 \mathrm{~mm}$, at the first FSH dose, produced more viable embryos $(9.6 \pm 6.0, P<0.05)$ compared to ewes that had follicles $>4 \mathrm{~mm}$ at the beginning of the SOV $(2.9 \pm 3.1$, viable embryos). Both the TRAD and DO+GnRH groups had fewer animals with large follicles $(>4 \mathrm{~mm})$ at the first FSH dose than the DO-GnRH group (P< 0.05). In conclusion, both the TRAD and DO+GnRH treatments induced a more favorable ovarian condition (follicles $\leq 4 \mathrm{~mm})$ for adequate SOV; although, all three treatments exhibited similar efficacies in Santa Inês sheep.

Key words: day 0 protocol, ewe, follicular population, GnRH, MOET.

Três protocolos para produção in vivo de embriões em ovelhas Santa Inês

RESUMO: Ainda não há consenso sobre qual é o protocolo mais apropriado para a produção in vivo de embriões em ovinos, apesar do crescente conhecimento. Uma abordagem para mitigar a variabilidade de resposta de ovelhas à superovulação (SOV) é iniciar a aplicação de gonadotrofinas em uma condição ovariana favorável. O presente estudo comparou três tratamentos em delineamento do tipo crossover: protocolo de SOV tradicional (TRAD) e "Dia 0" DO SOV sem (D0-GnRH) ou com GnRH (D0+GnRH). Quinze ovelhas Santa Inês foram superovuladas com $200 \mathrm{mg}$ de FSH em seis doses decrescentes e receberam PGF2a na quinta dose de FSH. As ovelhas foram submetidas a monta natural com carneiros férteis e os embriões colhidos por via cirúrgica. O número de embriões viáveis não diferiu entre os tratamentos $(T R A D=6,0 \pm 4,7 ; D 0-G n R H=3,8 \pm 6,4 ; D 0+G n R H=7,5 \pm 6,5)$. Independentemente do tratamento, ovelhas com foliculos $\leq 4$ mm na primeira dose de FSH produziram mais embriões viáveis $(9,6 \pm 6,0 ; P<0.05)$ quando comparadas aos animais que apresentavam foliculos $>4 \mathrm{~mm}$ no início da SOV (2,9 \pm 3,1 embriões viáveis). Os grupos TRAD e D0+GnRH apresentaram menor número de animais com folículos grandes (> $4 \mathrm{~mm})$, no momento da primeira dose de FSH, quando comparados ao grupo D0-GnRH (P<0,05). Em conclusão, os protocolos TRAD e DO+GnRH induziram uma condição ovariana mais favorável (folículos $\leq 4 \mathrm{~mm}$ ) para a SOV. No entanto, os três tratamentos apresentaram eficiência semelhante em ovelhas Santa Inês.

Palavras-chave: protocolo dia 0, ovinos, população folicular, GnRH, MOTE.

\section{INTRODUCTION}

Multiple ovulation and embryo transfer (MOET) programs contribute to the sheep production industry by providing an increased number of descendants from genetically superior donors (COGNIÉ et al., 2003). The main factor limiting these techniques is the variability in ovarian responses to superovulation (SOV) and; consequently, the number of viable embryos collected per ewe (BRUNOGALARRAGA et al., 2015).

One approach to mitigate this variability is to initiate gonadotropin administration under favorable ovarian conditions. The ovarian follicular status at the beginning of SOV directly affects the success of the MOET programs. In sheep, the ovarian response to FSH treatment is related positively to the number of small follicles $(2-3 \mathrm{~mm})$, and negatively 
to the presence of large follicles at the beginning of the SOV (GONZÁLEZ-BULNES et al., 2002). Despite the data indicating better embryo output in sheep without a large follicle and with higher antral follicular count (AFC), protocols that do not lead to this specific ovarian condition (10 to 14 days progestogen treatment) at the beginning of SOV can still show satisfactory results and are widely used (GONZÁLEZ-BULNES et al., 2003; BARTLEWSKI et al., 2008; MENCHACA et al., 2009; BERGSTEINGALAN et al., 2019). Progesterone-based long-term treatments block LH surge and allow a new cohort of follicles to grow. Currently, SOV treatment can be implemented to induce a supraphysiological number of follicles to grow.

The synchronization of ovulation before SOV is useful to prevent the presence of large follicles, allowing the start of SOV at the emergence of the first follicular wave after the induced ovulation. This approach was proposed by MENCHACA et al. (2009) and named as "Day 0 protocol". These authors reported a higher mean of transferable embryos (7.9) in Merino sheep after Day 0 treatment when compared to the animals that underwent a traditional (14 days of progestogen) SOV protocol (this last group producing a mean of 5.9 transferable embryos). However, the same methodology could not reach similar embryo outputs in Santa Inês sheep (LIMA et al., 2015; SOUZA-FABJAN et al., 2017; SANTOS et al., 2020).

Additionally, GnRH administration after estrus synchronization has been shown to improve ovulation synchrony and decreases the incidence of dominant follicles in sheep (REYNA et al., 2007; BALARO et al., 2016). When administering GnRH $36 \mathrm{~h}$ after progestogen device removal, the presence of a dominant follicle ( $>5 \mathrm{~mm}$ in diameter) was reduced but still occurred in $8 \%$ of ewes (SOUZAFABJAN et al., 2017). We hypothesized that the Day 0 protocol associated with early GnRH administration would benefit sheep SOV. Due to the inconsistent response to SOV in Santa Inês ewes, the present study compared a traditional SOV treatment to the Day 0 protocol with or without $\mathrm{GnRH}$ administered at $12 \mathrm{~h}$ after the progestogen device removal, before superovulation.

\section{MATERIALS AND METHODS}

This study was performed in Cachoeiras de Macacu, Rio de Janeiro (latitude 22 $27^{\prime} \mathrm{S}$ ), Brazil. A total of 15 healthy, non-pregnant Santa Inês ewes, aging two to five years, weighing 46.3 $\pm 6.2 \mathrm{~kg}$ and with a body condition score of $3.0 \pm$ 0.3 (scale 1-5) were used. Ewes were maintained in a shelter with unlimited access to pasture (Panicum sp. and Brachiaria sp.), water and mineralized salts. Additionally, chopped elephant grass (Pennisetum purpureum) was offered twice daily, and $300 \mathrm{~g}$ of concentrate $(17 \%$ crude protein) was administered daily.

Three SOV treatments were tested (Figure 1): a traditional protocol (TRAD) and the Day 0 protocol with and without the use of GnRH (D0+GnRH, D0-GnRH, respectively). The ewes were subjected to all treatments in a crossover design, with three treatments and three repetitions ( $\mathrm{n}=5 /$ group/period). A 60 days interval was maintained between repetitions.

For TRAD, an intravaginal device (IVD) with $60 \mathrm{mg}$ of medroxyprogesterone acetate (Progespon ${ }^{\circledR}$, Schering Plough, São Paulo, Brazil) was inserted (D0) and maintained for 14 days. From D12 to D14, $200 \mathrm{mg}$ of follicle-stimulating hormone (FSH; Folltropin- $\mathrm{V}^{\circledR}$, Bioniche Animal Health, Ontario, Canada) was administered IM in six decreasing doses $(50 / 50,30 / 30$, and $20 / 20 \mathrm{mg}$ ) with a $12 \mathrm{~h}$ interval between each dose. On D14, the IVD was removed and $5 \mathrm{mg}$ of dinoprost (Lutalyse ${ }^{\circledR}$, Pfizer, São Paulo, Brazil) was administered IM.

For the D0-GnRH group, at D5 (five days after IVD insertion), 300 IU of eCG (Novormon ${ }^{\circledR}$, Schering Plough, São Paulo, Brazil), and $5 \mathrm{mg}$ of dinoprost were administered IM. At D6, the first IVD was removed and at D8, a new IVD was inserted and the same FSH treatment described for the TRAD protocol was followed. At D10, the second IVD was removed and $5 \mathrm{mg}$ of dinoprost was administered IM. The $\mathrm{D} 0+\mathrm{GnRH}$ group received the same hormonal treatment as previously described for the D0-GnRH group, but $0.025 \mathrm{mg}$ of lecirelin (Gestran Plus ${ }^{\circledR}$, Tecnopec, São Paulo, Brazil) was administered IM $12 \mathrm{~h}$ after removal of the first IVD (D6.5).

Estrus detection was performed every $12 \mathrm{~h}$ immediately after the last FSH dose with the aid of a teaser male. Ewes showing estrus were naturally mated with one of three adult rams previously approved by a breeding soundness exam. The rams were rotated between the five groups of ewes every $12 \mathrm{~h}$.

Ovarian follicles were observed by realtime transrectal ultrasonography using a portable device equipped with a $5.0 \mathrm{MHz}$ linear transducer (Aloka SSD-500, Tokyo, Japan). Ovaries were located, and the number, diameter, and position of ovarian follicles were recorded every $12 \mathrm{~h}$ from the first FSH dose until ovulation. First ovulation was 


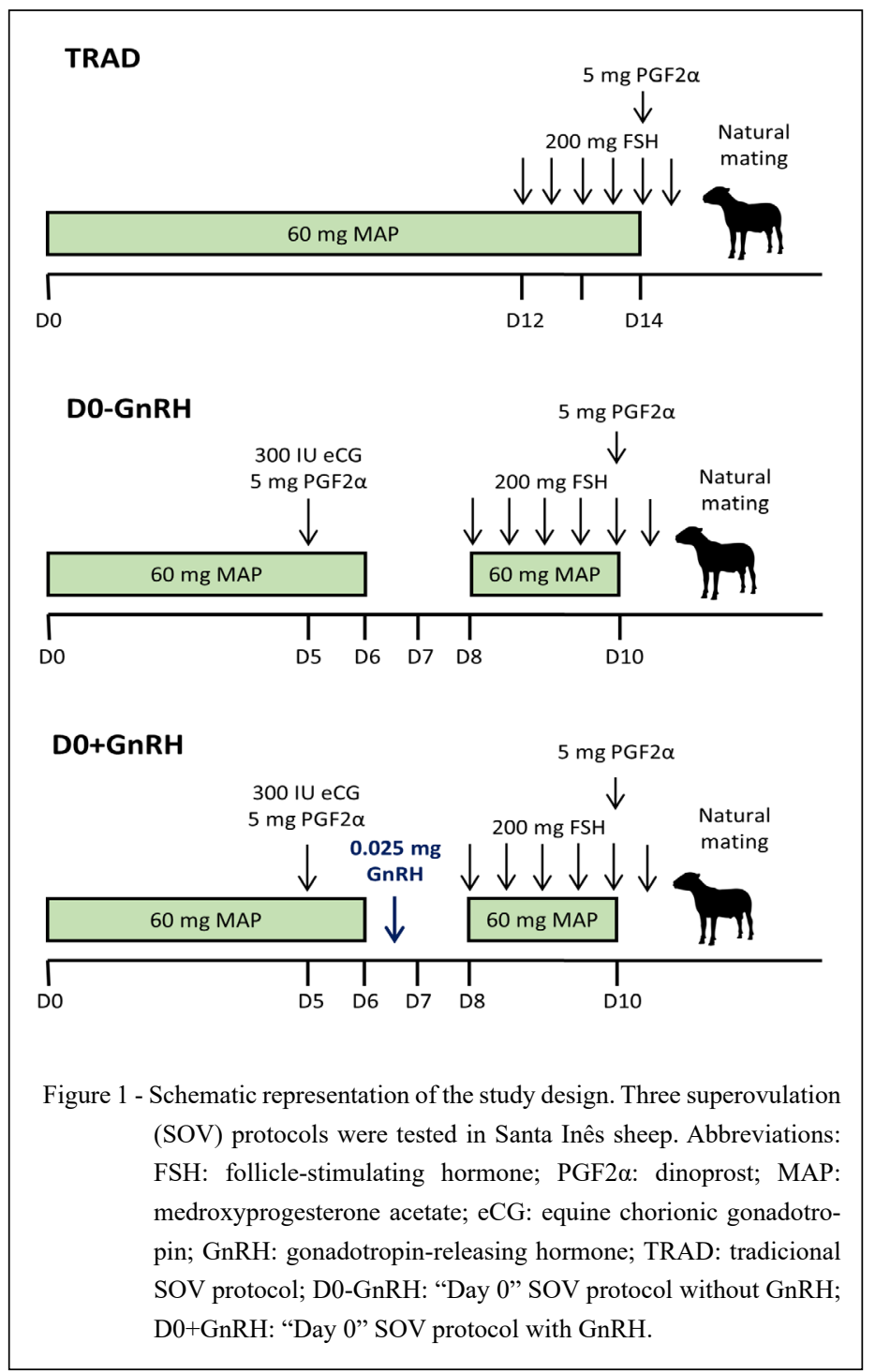

defined when at least one large follicle visualized in the last examination was no longer detected. The number of corpora lutea (CL) was determined by laparoscopy 6-7 d after natural mating. Ewes bearing $\leq 3$ CLs were considered non-responsive to SOV and were not subjected to the embryo recovery procedure.

Embryos were recovered via longitudinal ventral laparotomy. Sedation was induced using propofol at a maximum IV dose of $4 \mathrm{mg} / \mathrm{kg}$ (Profolen $^{\circledR}$, Balusiegel, Cotia, Brazil) and $0.1 \mathrm{mg} /$ kg diazepam (diazepam $10 \mathrm{mg}$, Santisa, Bauru, São Paulo, Brazil). General anesthesia was induced and maintained by inhalation of isoflurane (Forane $^{\circledR}$;
Abbott Laboratories, São Paulo, Brazil). Each uterine horn was flushed with $40 \mathrm{~mL}$ of modified Dulbecco's phosphate-buffered saline at $37^{\circ} \mathrm{C}$, using an 18 -gauge IV catheter inserted near the utero-tubal junction. Embryos were recovered in a petri dish using a Foley catheter inserted at the external bifurcation of the uterine horns. During this procedure, the genital tract was constantly washed with heparinized saline solution (4 IU/ mL) (Liquemine ${ }^{\circledR}$, Roche, Rio de Janeiro, Brazil) at $37^{\circ} \mathrm{C}$.

Embryos were morphologically evaluated under a stereomicroscope (Nikon, Tokyo, Japan) at a magnification of $20 \mathrm{X}$ to $40 \mathrm{X}$ and classified according 
to the criteria recommended by the International Society of Embryo Transfer (STRINGFELLOW \& SEIDEL, 1998). The number of viable and non-viable (zona pellucida, degenerated, unfertilized) structures were recorded.

The variables were tested for normality using the Lilliefors test, and ANOVA, followed by either Tukey or Student-Newman-Keuls test. Nonparametric data were analyzed using Fisher's exact test and for independent samples, the Mann-Whitney test was used. Data were analyzed using the $\mathrm{SAEG}^{\circledR}$ software. Statistical significance was set at $\mathrm{P}<0.05$.

\section{RESULTS}

After SOV, the estrus response rate was similar $(\mathrm{P}>0.05)$ in the three treatments: TRAD $(100 \%, 15 / 15), \quad$ D0-GnRH $(87 \% ; 13 / 15)$, and D0+GnRH (93\%; 13/14 [one ewe lost the IVD during SOV and her data was not considered]). There was no significant difference $(\mathrm{P}>0.05)$ in estrus behavior parameters (average values of estrus onset, estrus duration, IVD removal to first ovulation and the interval from estrus onset to first ovulation). Estrus onset was more concentrated in the $\mathrm{D} 0+\mathrm{GnRH}$ group
(Figure 2). The number of ewes that responded to SOV ( $\geq 4 \mathrm{CL}$ ) and the number of viable and nonviable structures recovered were similar among the treatments (Table 1).

The follicular population could not be determined in two of the 23 ewes that responded to SOV because the ultrasonography examination was interrupted due to rectal bleeding. At the first FSH dose, $42.8 \%$ (18/42) of the ewes had follicles $>4 \mathrm{~mm}$, $27.7 \%(5 / 18)$ from TRAD, $61.1 \%(11 / 18)$ from D0GnRH, and $11.1 \%(2 / 18)$ from D0+GnRH. Both the TRAD and D0+GnRH groups had fewer animals with large follicles at the first FSH dose than the D0GnRH group $(\mathrm{P}<0.05)$. As there was no difference in embryo yield between treatments, response to SOV data was grouped to evaluate the impact of follicular size on embryo quanti-qualitative yield (Figure 3). Overall, in ewes that responded to SOV, the presence of follicles $\leq 4 \mathrm{~mm}$ at the beginning of SOV improved the number of viable embryos recovered (Figure 3 ).

\section{DISCUSSION AND CONCLUSION}

The number of viable embryos did not differ significantly among groups; however,

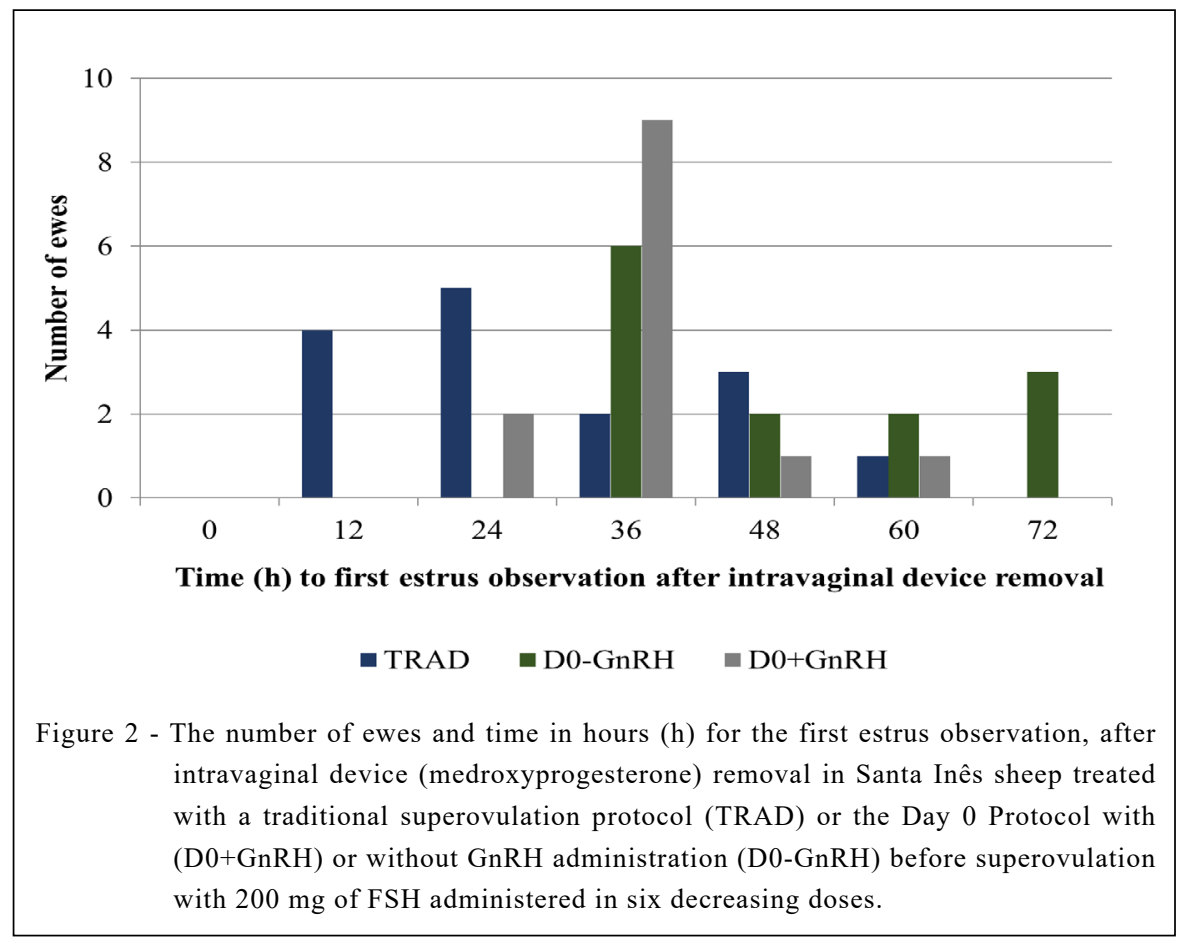

Ciência Rural, v.52, n.8, 2022. 
Table 1 - Data of Santa Inês ewes submitted to three different superovulation protocols (SOV) for in vivo embryo production. Are presented the percentage of ewes that responded to SOV (i.e., bearing $\geq 4$ corpora lutea at embryo recovery) and the quantitative-qualitative yields of the recovered structures.

\begin{tabular}{lccc}
\hline Endpoints & TRAD $^{\#}$ & D0-GnRH & D0+GnRH $^{\#}$ \\
\hline Responded $(\geq 4$ CL; \%) & $60.0(9 / 15)$ & $40.0(6 / 15)$ & $57.1(8 / 14)$ \\
Total structures & $8.4 \pm 4.4$ & $9.5 \pm 6.3$ & $11.7 \pm 10.3$ \\
Viable embryos & $6.0 \pm 4.7$ & $3.8 \pm 6.4$ & $7.5 \pm 6.5$ \\
Degenerated & $0.4 \pm 0.7$ & $0.2 \pm 0.4$ & $0.2 \pm 0.7$ \\
Unfertilized & $1.9 \pm 3.2$ & $4.0 \pm 3.2$ & $3.9 \pm 6.1$ \\
Zona pellucida & $0.1 \pm 0.3$ & $1.5 \pm 1.9$ & $0.1 \pm 0.3$ \\
\hline
\end{tabular}

\#TRAD: traditional SOV treatment (14 days of progestogen); ${ }^{\#} \mathrm{D} 0-\mathrm{GnRH}$ - SOV starting after an estrus synchronization protocol; \# D0+GnRH: similar protocol to D0-GnRH, but with GnRH; CL - corpora lutea. Different letters within a row indicate significant differences $(\mathrm{P}<0.05)$.

regardless of the treatment, ewes with follicles $\leq 4$ $\mathrm{mm}$ during the first FSH dose produced more viable embryos than ewes with follicles $>4 \mathrm{~mm}$ (Figure 3 ). $\mathrm{D} 0+\mathrm{GnRH}$ was very efficient in promoting follicular wave synchronization, as $85.7 \%$ of the females did not have follicles $>4 \mathrm{~mm}$ at the beginning of the SOV. It has been suggested that when the SOV treatment starts in the presence of a large follicle, there is a lower number of small follicles that can be recruited for growing, leading to a decrease in the number of ovulations and, consequently, lower embryo production (GONZÁLEZ-BULNES et al., 2002; MENCHACA et al., 2009). In our experiments, despite the low number of large follicles in the $\mathrm{D} 0+\mathrm{GnRH}$ group, no statistically significant difference was observed in SOV efficiency among the groups (Table 1).

The presence of a higher number of ewes with large follicles in the D0-GnRH group than in the D0+GnRH group (11 and 2, respectively), is possibly due to GnRH administration on D6.5. According to MENCHACA et al. (2010), the use of GnRH after sponge removal (during estrus synchronization before SOV) prevents the establishment of dominant follicles and increases the number of females responsive to SOV. In addition, SILVA et al. (2015), in a study on Santa Inês sheep, reported that when GnRH was applied in estrus synchronization protocols all ewes ovulated but, in protocols without GnRH 20 to $30 \%$ did not ovulate.

From three replicates of TRAD treatment, follicles with diameters $>4 \mathrm{~mm}$ were observed in five females. Previous studies demonstrated that in long-term treatments with progesterone devices, there is a decrease in serum concentration of this hormone, which allows the maintenance of persistent follicle (VIÑOLES et al., 1999; RUBIANES \& MENCHACA, 2006; MENCHACA et al., 2009). This phenomenon could explain the occurrence of large follicles in the TRAD group.

An interesting finding of the present study was that some ewes with persistent follicles at the beginning of the SOV had a high ovulation rate and/or a high number of viable structures. It is possible that these large follicles were in atresia, which could explain why they did not interfere with the new recruitment, follicular growth, and ovulation (GONZÁLEZ-BULNES et al., 2002; VEIGALOPEZ et al., 2008).

The number of ewes that responded to SOV ( $\geq 4 \mathrm{CL}$ ) in this experiment did not differ among the groups (Table 1). When the ewes from D0-GnRH and $\mathrm{D} 0+\mathrm{GnRH}$ groups were subjected to a method similar to that used by MENCHACA et al. (2009) (Day 0), they showed a lower SOV response $(6.1 \pm 5.8 \mathrm{CL}$ and $8.5 \pm 5.3 \mathrm{CL}$, respectively) when compared to the SOV response reported by these authors $(13.5 \pm 1.4$ CL). According to MENCHACA et al. (2009), the use of GnRH at the end of SOV treatment is associated with a better ovulatory response. Thus, the lower response observed in our study may be due to the absence of GnRH at the end of the SOV.

The number of total structures recovered did not differ significantly among the groups. A wide variation among animals was observed for this parameter. This disparity in embryo production, as well as the variability of ovarian response to SOV, has been reported by several researchers and remains 


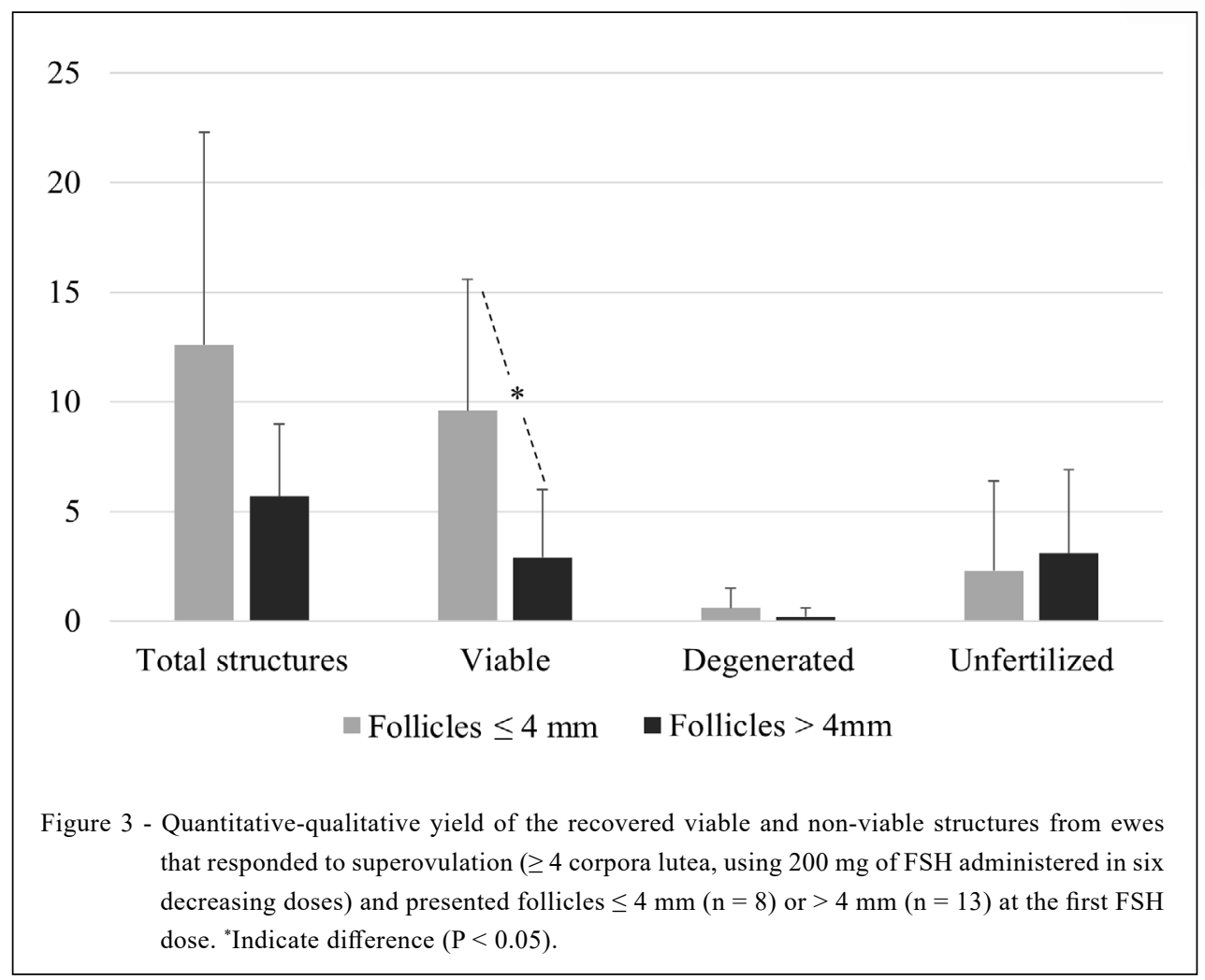

a major limitation for MOET in sheep (COGNIÉ et al., 2003; BRUNO-GALARRAGA et al., 2015). Factors related to the animals (breed, age, follicular count, and anti-Müllerian concentration) or external factors (protocol, progesterone source and profile, and gonadotropin used) are related to the variability in response (NAQVI et al., 2000; GONZÁLEZBULNES et al., 2003; GONZÁLEZ-BULNES et al., 2004; PINTO et al., 2018).

In conclusion, under the conditions of the present study, both the TRAD and D0+GnRH treatments induced a more favorable ovarian condition (follicles $\leq 4 \mathrm{~mm}$ ) for adequate $\mathrm{SOV}$; although, the three treatments reached similar efficiency in Santa Inês sheep.

\section{ACKNOWLEDGEMENTS}

The authors would like to thank Fundação Carlos Chagas Filho de Amparo à Pesquisa do Estado do Rio de Janeiro (FAPERJ) for funding this project. FZB, JMGS-F, and JFF are fellows of the Conselho Nacional de Desenvolvimento Científico e Tecnológico (CNPq), and JMGS-F is also a FAPERJ fellow. And was financed in part by the Coordenação de Aperfeiçoamento de Pessoal de Nível Superior (CAPES), Brasil - Finance code 001.

\section{BIOETHICS \\ AND \\ BIOSECURITY \\ COMMITTEE APPROVAL}

All procedures described in this manuscript were approved by the Ethical Committee for Animal Use of the Universidade Federal Fluminense (protocol \#062/08) and followed the guidelines of the Conselho Nacional de Controle de Experimentação Animal (CONCEA). The experiments were conducted according to the ethical principles of the Sociedade Brasileira de Ciência em Animais de Laboratório.

\section{DECLARATION OF CONFLICTS OF INTEREST}

We have no conflicts of interest to declare.

\section{AUTHOR'S CONTRIBUTIONS}

All authors contributed equally to the conception and writing of this manuscript. The authors have critically revised the manuscript and approved the final version.

\section{REFERENCES}

BALARO, M. F. A. et al. Potential role for GnRH in the synchronization of follicular emergence before the superovulatory 
Day 0 protocol. Domestic Animal Endocrinology, v. 54, p. $10-14,2016$. Available from: <https://doi.org/10.1016/j. domaniend.2015.07.002>. Accessed: Feb. 15, 2020. doi:_10.1016/j. domaniend.2015.07.002.

BARTLEWSKI, P. M. et al. Ovarian and endocrine determinants of superovulatory responses in anestrous ewes. Small Ruminant Research v. 75 , p. $210-216,2008$. Available from: $<$ https://doi. org/10.1016/j.smallrumres.2007.11.003>. Accessed: Jul. 12, 2021. doi: 10.1016/j.smallrumres.2007.11.003.

BERGSTEIN-GALAN, T. G. et al. Effect of semen and donor factors on multiple ovulation and embryo transfer (MOET) in sheep. Reproduction in Domestic Animals v. 54, p. 401-407, 2019. Available from: <https://doi.org/10.1111/rda.13381> Accessed: Jul. 12, 2021. doi: 10.1111/rda.13381.

BRUNO-GALARRAGA, M. M. et al. Preselection of high and low ovulatory responders in sheep multiple ovulation and embryo transfer programs. Theriogenology, v. 84, p. 784-90, 2015. Available from: <https://doi.org/10.1016/j. theriogenology.2015.05.011>. Accessed: Mar. 20, 2020. doi 10.1016/j.theriogenology.2015.05.011.

COGNIÉ, Y. et al. Current status of embryo technologies in sheep and goat. Theriogenology, v. 59, p. 171-188, 2003. Available from: $<$ https://doi.org/10.1016/s0093-691x(02)01270-0>. Accessed: Mar. 20, 2020. doi: 10.1016/s0093-691x(02)01270-0.

GONZÁLEZ-BULNES, A. et al. Effects of ovarian follicular status on superovulatory response of dairy goats to FSH treatment. Small Ruminant Research, v. 48, p. 9-14, 2003. Available from: <https://doi.org/10.1016/S0921-4488(02)00294-8>. Accessed: Mar. 15, 2020. doi: 10.1016/S0921-4488(02)00294-8.

GONZÁLEZ-BULNES, A. et al. Measurement of inhibin A and follicular status predict the response of ewes to superovulatory FSH treatments. Theriogenology, v. 57, p. 1263-1272, 2002. Available from: $\quad<$ https://doi.org/10.1016/s0093-691x(01)00723-3>. Accessed: Apr. 18, 2020. doi: 10.1016/s0093-691x(01)00723-3.

GONZÁLEZ-BULNES, A. et al. Multiple factors affecting the efficiency of multiple ovulation and embryo transfer in sheep and goats. Reproduction, Fertility, and Development, v. 16, p. 421435, 2004. Available from: <https://doi.org/10.10371/rd04033>. Accessed: May. 10, 2020. doi: 10.10371/RD04033.

LIMA, J. T. M. A. et al. Effect of natural mating or laparoscopic artificial insemination in superovulated Santa Inês ewes on superovulatory response, fertility and embryo viability. Animal Production Science, v. 56, p. 1-4, 2015. Available from: $<$ https:// doi.org/10.1071/AN14827>. Accessed: Feb. 15, 2020. doi 10.1071/AN14827.

MENCHACA, A. et al. Progesterone treatment, FSH plus eCG, GnRH administration, and Day 0 Protocol for MOET programs in sheep. Theriogenology, v. 72, p. $477-$ 483, 2009. Available from: <https://doi.org/10.1016/j. theriogenology.2009.04.002>. Accessed: Feb. 15, 2020. doi 10.1016/j.theriogenology.2009.04.002.

MENCHACA, A. et al. New approaches to superovulation and embryo transfer in small ruminants. Reproduction, Fertility, and Development, v. 22, p. 113-118, 2010. Available from: <https:// doi.org/10.1071/rd09222>. Accessed: May. 10, 2020. doi: 10.1071/ rd09222.
NAQVI, S. M. K. et al. Effect of Superovulatory Regimens on Ovarian Response and Embryo Production in Fine Wool Sheep in Tropics. Asian-Australasian Journal of Animal Sciences, v. 13 , p. $595-599,2000$. Available from: <https://doi.org/10.5713/ ajas.2000.595>. Accessed: May. 10, 2020 doi: 10.5713/ ajas.2000.595.

PINTO, P. H. N. et al. Anti-Müllerian hormone and antral follicle count are more effective for selecting ewes with good potential for in vivo embryo production than the presence of $\mathrm{FecG}^{\mathrm{E}}$ mutation or eCG pre-selection tests. Theriogenology, v. 113, p. 146-152, 2018. Available from: <https://doi.org/10.1016/j. theriogenology.2018.02.018>. Accessed: Jul. 12, 2021. doi: 10.1016/j.theriogenology.2018.02.018.

REYNA, J. et al. Synchrony of ovulation and follicular Dymics in Merino ewes treated with GnRH in the breeding and nonbreeding seasons. Reproduction in Domestic Animals, v. 42, p. 410-417, 2007. Available from: <https://doi.org/10.11 11/j.1439-0531.2006.00800.x>. Accessed: Jul. 12, 2021. doi: 10.1111/j.1439-0531.2006.00800.x.

RUBIANES, E.; MENCHACA A. Follicular dynamics, oestrous synchronisation and superovulation in sheep. Acta Scientiae Veterinariae, v. 34 , p. 251-261, 2006. Available from: <http:// www.ufrgs.br/actavet/34-suple/anais\%20INGLES_sbte2006.pdf>. Accessed: Apr. 20, 2021.

SANTOS, J. D. R. et al. Transcervical vs. laparotomy embryo collection in ewes: The effectiveness and welfare implications of each technique. Theriogenology, v. 153, p. $112-121$, 2020. Available from: <https://doi.org/10.1016/j. theriogenology.2020.05.004>. Accessed: Nov. 22, 2020. doi: 10.1016/j.theriogenology.2020.05.004.

SILVA, B. D. M. et al. Ovulation induction in ewes using GnRH in long and short-term synchronization protocols. Animal Reproduction, v. 12, p. 312-315, 2015. Available from: <https:// www.animal-reproduction.org/article/5b5a6037f7783717068b462 a>. Accessed: Feb. 15, 2020.

SOUZA-FABJAN, J. M. G. et al. Effect of different hormonal combinations on follicular wave emergence and superovulatory response in sheep. Theriogenology, v. 103, p. 24-29, 2017. Available from: <https://doi.org/10.1016/j. theriogenology.2017.07.036>. Accessed: Feb. 15, 2020. doi: 10.1016/j.theriogenology.2017.07.036.

STRINGFELlOW, D. A., SEIDEL, S. M. Manual of the International Embryo Transfer Society, $3^{\text {rd }}$ edn. Savory. Champaign, IL, USA, 1998. Available from: <https://www.iets. org/Publications/IETS-Manual>. Accessed: Apr. 20, 2015.

VEIGA-LOPEZ, A. et al. Timing of preovulatory LH surge and ovulation in superovulated sheep are affected by follicular status at start of the FSH treatment. Reproduction in Domestic Animals, v. 43, p. 92-98, 2008. Available from: <https://doi.org/1 0.1111/j.1439-0531.2007.00860.x>. Accessed: Feb. 15, 2020. doi: 10.1111/j.1439-0531.2007.00860.x.

VIÑOLES, C. et al. The effect of subluteal levels of exogenous progesterone on follicular dynamics and endocrine patterns during the early luteal phase of the ewe. Theriogenology, v. 51, p. 13511361, 1999. Available from: <https://doi.org/10.1016/S0093691X(99)00079-5>. Accessed: May. 10, 2020. doi: 10.1016/ S0093-691X(99)00079-5. 